\title{
FDI And Economic Growth In CEE And MENA Countries: A Tale Of Two Regions
}

Samer Kherfi, (Email: skherfi@aus.edu), American University of Sharjah, UAE Mohamed Soliman, (email: msoliman@aus.edu), American University of Sharjah, UAE

\begin{abstract}
This paper examines the effect of foreign direct investment (FDI) on economic growth in two different regions: Central and Eastern Europe (CEE) and the Middle East and North Africa (MENA). The main findings of our analysis suggest that FDI has a positive effect on growth only in EU accession countries while the effect of FDI on growth in MENA and non-EU accession countries is negative. Candidacy to EU membership is considered as a driving force for stronger commitment and more serious reforms that may have led to the positive effect of FDI on growth.
\end{abstract}

\section{INTRODUCTION}

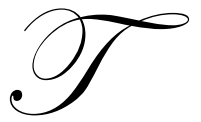

his paper examines the effect of foreign direct investment (FDI) on economic growth in 23 countries of two regions, the Middle East and North Africa (MENA) and Central and Eastern Europe (CEE). These economies have a common experience as they started comparable reform agendas based on privatization, financial and trade liberalization, and major institutional and legal system reforms to foster a market oriented economic system. In their efforts to reform, MENA and CEE countries sought FDI to bring the much-needed package of capital, technology, expertise and access to export markets. Reform in CEE countries is marked by the collapse of the former Soviet Union and then by plans to access the European Union (EU). MENA reforms started in the late 1980s after the failure of the region's inward looking development strategy. The example of the South East Asian "tigers" was frequently cited in official speeches around the region as the model to follow. Attracting FDI and promoting exports were identified as the new sources of growth for MENA countries.

Nevertheless, these two regions have inherently different economic structures and socio political layouts. Moreover, the speed and depth of reforms varied across the two regions in a way that shaped their fortunes in terms of the volume of FDI inflows ant its contribution to growth. In particular, changes in CEE countries were more revolutionary compared to the gradual changes that took place in MENA. Moreover, CEE reforms reflected the aspiration to join the European Union (EU) and subsequently many CEE countries had to meet strict convergence criteria as part of their EU accession arrangements. Indeed, accession to the EU seems to be a decisive factor for the effect of FDI on growth as we show in this paper.

Despite the ample literature on FDI and growth in developing countries, there is very little empirical work on the impact of FDI on growth in MENA countries. Empirical investigation of FDI impact on CEE economies has been hampered by the lack of sufficient data due to the short history of FDI in the region. This paper attempts to contribute to the literature on FDI and growth by comparing the impact of FDI on growth in these two relatively unexplored areas. And unlike most existing literature, we utilize a panel data set to allow for both country and time effects. The findings of our analysis have important policy implication. By contrasting FDI performance in two regions with different paces of transition we can draw some lessons and guidelines for policy makers in their search for a better growth contribution of FDI.

This paper proceeds as follows: section 2 briefly reviews the literature on FDI and growth. Section 3 describes some FDI facts and trends in the two regions, and section 4 provides the theoretical framework. Section 5 describes our data and empirical model and summarizes the main findings. In section 6 we conclude with some remarks and policy implications. 


\section{FDI AND GROWTH}

The link between FDI and growth has been subject to intense debate. Endogenous growth theory as in Grossman and Helpman (1991) provides a commonly adopted conceptual framework for analyzing the impact of FDI. Fore instance, Romer (1993) argues that FDI by means of technology and knowledge transfer may actually help narrow ideas gap between the rich and the poor. There is a growing body of empirical literature stressing FDI as one potential engine of economic growth. For instance, Chen, et al (1995) find that FDI inflows are positively correlated with post-1978 economic growth in China by contributing to capital formation, export earnings, and bringing about advanced managerial skill. Blomstrom, et al (1992) provide similar evidence using a panel data from 78 developing countries where technological upgrading and knowledge spillovers are the vehicle through which FDI influences growth.

However, Balasubramanyam, et al (1996) and Agrawal (2000) argue that the effect of FDI inflows on growth in developing countries could possibly go both ways and the positive effect is conditional to openness to international trade. This result confirms Bhagwati's hypothesis (see Bhagwati, 1978) that the volume and efficiency of FDI in export promotion economies are more likely to exceed their levels in import substitution countries. Host country characteristics are also emphasized in Borensztein, et al (1998) who argue that FDI is an important vehicle for technology diffusion only when the host country's human capital stock achieves a certain threshold. Recent work by Nair-Reichert and Weinhold (2001) uses a sample of 24 developing countries and find a positive causal relationship running from FDI to economic growth. Similarly Makki and Somwaru (2004) examine the impact of FDI on economic growth in 66 developing countries and identify FDI as a major source in stimulating domestic investment and growth.

However, there are some studies that argue that FDI does not accelerate growth, see for example Kasibhatla and Sawhney (1996) and Akinlo (2004). Conceptually, it is argued as in Brecher and Diaz-Alejandro (1977) that FDI may have a negative influence on growth in the host economy by means of extracting excessive profits. Policy makers in developing countries, however, have long ago adopted the view that FDI is beneficial to economic growth. This resulted in a global competition for FDI inflows in which MENA and CEE countries have been increasingly involved.

\section{FDI FACTS AND TRENDS}

Two major events have reshaped MENA countries attitude towards free trade and FDI: the debt crisis in the early 1980s and the resulting drain in commercial bank lending to developing countries, and the success of export-led growth experience in South East Asian economies in contrast with the unsuccessful import-substitution strategies that had been widely adopted in many MENA countries. But it was only in the late 1980s when MENA countries started to act seriously to shift towards greater trade and FDI openness when declining oil revenues added more restraints. MENA countries then appeared to be less hesitant to take serious steps towards creating an environment conducive to FDI and exports. However, attracting FDI became more challenging given the repeated political turmoil in the region.

Against this background and with the increasing global competition for FDI, MENA countries accelerated the pace of FDI and trade liberalization. Reforms generally included new FDI legislations like in Morocco in 1983 and in Egypt in 1989. These legislations were overhauled in major revisions in 1988 and 1995 in Morocco and in 1997 in Egypt. Tunisia and Turkey also introduced new legislations to promote FDI in 1993 and in 1995, respectively. Similarly, a new investment code was adopted in Algeria in 1991. The spirit of most of these legislations is to do away with controls that limit FDI activities to certain sectors and to remove restrictions on repatriation. National agencies were established to streamline procedures for FDI entrance. A major component of these legislations emphasized property rights and its protection.

On the other hand, CEE countries road to the market economy started after the collapse of the former Soviet Union. In the early 1990s, CEE countries introduced massive privatization programs, which attracted sizeable FDI inflows. FDI accelerated with the progress in foreign exchange markets and financial markets liberalization. Attracting FDI, ever since, has been a key element in the national policy framework in CEE countries. They introduced new laws and regulations that grant foreign capital protection, profit repatriation guarantees and in many 
cases 100 percent ownership. Some countries, however, retained some operating restrictions on foreign firms working in "strategic" sectors as arms manufacturing in Bulgaria. As shown in table 2, Poland is the top recipient of FDI with an annual average of more than \$5bn in 1990-2002, followed by the Czech Republic with an average of \$3.8bn. Together, Poland and the Czech Republic managed to attract more FDI than the six MENA countries in our sample combined. Other countries, such as Moldova and the Baltic republics, were not as successful, with FDI flows below those of MENA countries. Israel leads MENA countries followed by Turkey and then Egypt who once was among the top five developing countries in terms of FDI inflows.

As the two regions have different fortunes in attracting FDI, they also differ in their socio economic structures. As shown in tables 3 and 4, EU accession candidates, on average, have higher human capital stock, per capita GDP and investment ratios than MENA countries. They also enjoy lower foreign debt and lower inflation and they are more export oriented than their MENA counterparts.

\section{THE MODEL}

To test the impact of FDI on economic growth we use a model derived from a conventional production function in which FDI is an additional input along with labor and domestic physical capital (see also Balasubramanyam, et al 1996). FDI represents the source of foreign ideas, advanced technology, managerial skills and innovative products. The production function can be written as:

$Y_{\text {it }}=f\left(K_{i t} ; F_{i t} ; L_{i t}\right)$

where $i$ and $t$ represent country and time indicators. $Y_{i t}$ is real GDP; $K_{i t}$ is the domestically financed capital stock; $\mathrm{F}_{\mathrm{it}}$ is the foreign financed capital stock; and $L_{i t}$ represents labor force. Assuming equation (1) is log linear, taking $\operatorname{logs}$ and differencing, we obtain the following:

$\mathrm{y}_{\mathrm{it}}=\alpha+\beta \mathrm{k}_{\mathrm{it}}+\gamma \mathrm{f}_{\mathrm{it}}+\lambda \mathrm{l}_{\mathrm{it}}+\theta \mathrm{Z}_{\mathrm{it}}+\xi_{\mathrm{it}}$

where $k_{i t}, f_{i t}$ and $l_{i t}$ are the growth rates of domestic capital stock, foreign capital stock and labor force. $Z_{i t}$ is the set of other control variables. In our empirical model we use FDI and domestic investment $(I)$ relative to GDP to approximate the growth rate of foreign and domestic capital as done in many studies including Agrawal (2000). We also include $\mathrm{H}_{\mathrm{it}}$ and $\mathrm{Y}_{\mathrm{i} 0}$ to represent the stock of human capital and the initial GDP level respectively as in Borensztein et al (1998). $\mathrm{H}_{i t}$ is included because a higher level of human capital may help the host country absorb advanced technology embodied in FDI inflows. The inclusion of the initial level of real GDP is intuitive as countries starting off with high levels of GDP find it more difficult to grow fast. We also include foreign debt, inflation, and government consumption as impediment to growth, and exports to real GDP to capture the export led growth hypothesis. These are the most commonly used additional control variables in the literature. Our empirical model then becomes:

$\mathrm{y}_{\mathrm{it}}=\alpha+\beta(\mathrm{FDI} / \mathrm{Y})_{\mathrm{it}}+\gamma(\mathrm{I} / \mathrm{Y})_{\mathrm{it}}+\phi \mathrm{H}_{\mathrm{it}}+\psi \mathrm{Y}_{\mathrm{i} 0}+\lambda \mathrm{l}_{\mathrm{it}}+\theta \mathrm{Z}_{\mathrm{it}}+\xi_{\mathrm{it}}$

where $y_{i t}$ indicates per capita GDP growth; $(F D I / Y)_{i t}$ is the ratio of FDI inflows to current GDP and is a proxy for investment rate of foreign investors; $(I / Y)_{i t}$ is the ratio of domestic investment to current GDP, which is a proxy for the investment rate of domestic investors; $H_{i t}$ is the level of human capital of host country and $l_{i t}$ represents the growth rate of the labor force. $Z_{i t}$ is a set of other control variables including government consumption to GDP, exports to GDP, foreign debt to GDP, and inflation.

\section{DATA AND ANALYSIS}

We obtained data on real per capita GDP, gross domestic investment, labor force, government consumption, inflation, exports and foreign debt from the World Bank's World Development Indicators. Data on FDI inflows are from the UNCTAD website. We use as a proxy for human capital the average years of education attained by adult population of 25 years old and above which is obtained from Barro and Lee (2000). For MENA countries FDI data are 
available since the late 1970s. For CEE countries, however, data are available since late 1980s, which allowed only an unbalanced data spanning from 1979 through 2002.

In order to exploit the time series dimension of the relationship between FDI and growth and to account for country specific factors, we construct 6-year averages for the periods 1979-1984, 1985-1990, 1991-1996, and 19972002. This allows 60 observations including 2 observations for each CEE country and 4 observations for each of the MENA countries. Table 1 lists the countries in the sample. They all share the same aspiration to attract foreign direct investment and integrate in the global economy.

Ordinary Least Squares estimates can be biased because of endogeneity problems arising from the possibility that FDI itself is attracted to high growth economies. In order to avoid endogeneity problems we use two stage least square (2SLS) estimation. We use as instruments for current FDI levels, one period lagged levels of FDI. Lagged FDI qualifies as instrument for it is highly correlated with current FDI but is uncorrelated with the error term. The first column of table 5 shows the results of our basic regression. Data seems to fit the model well and the null of joint zero coefficients is rejected at the one percent significance level. The coefficient on FDI is not statistically significant suggesting that FDI does not have any influence on growth.

We also use panel data regressions to allow for the country specific factors to be explored. We continue to use the same instruments as before. Column 3 of table 5 summarizes the results of the random effect instrumental variable estimates. The Hausman test favors the random effect over the fixed effect model. The null of joint zero coefficients is rejected at the one percent significance level. We observe that the effect of foreign debt and inflation on growth is negative and statistically significant. The effect of exports, domestic investment, and government consumption is not significant. The variable of interest, FDI has a negative but statistically insignificant coefficient suggesting that FDI does not influence the growth rate of real per capita income.

We adjust the regressions by introducing dummy variables to capture any MENA or EU accession effects. In columns 3 and 4 regressions in table 5, we add two interaction variables: FDI*EU and FDI*MENA. EU is a dummy variable that takes the value of 1 if the country is one of the EU accession candidates and 0 otherwise. MENA is a dummy variable that takes the value of 1 if the country belongs to the MENA region and the value of 0 otherwise. We use EU accession as an indicator of the comprehension and seriousness of reform. EU accession countries by and large have outperformed other transition economies in terms of the speed and coverage of the reform and showed stronger commitment as their accession to the EU was at stake. By contrast, other CEE and MENA countries were not subject to such pressure, although market reforms remained high on their agenda.

Columns 3 and 4 in table 5 show that the coefficient on FDI is now negative and statistically significant. The coefficient on FDI*MENA is insignificant and the coefficient on FDI*EU is positive and significant. Sings and magnitudes of the coefficients suggest that FDI has a positive $(7.15-5.49=1.66)$ and statistically significant effect on growth in EU accession countries. Meanwhile, the coefficient on FDI is now negative (-5.49) and statistically significant for the omitted group (non-accession CEE countries). Furthermore, the effect of FDI in MENA countries is not statistically different from that in non-accession CEE countries, implying that the effect on MENA countries is significantly negative. These results suggest the importance of controlling for country specific factors. When we estimated one coefficient for all MENA and CEE countries combined, the effect of FDI was insignificant. However, by differentiating between 3 groups of countries, we found that FDI promotes growth in EU accession countries but not in MENA or non-accession CEE countries. Apparently, the degree of commitment to, and depth of, reforms is an important determinant of the effects of FDI on growth.

Previous studies as in Borensztein, et al (1998) stress the importance of the stock of human capital for FDI to have a positive effect on economic growth. We therefore introduce $(\mathrm{FDI} * \mathrm{H})$ as an additional interaction variable to capture the role of human capital. We also take this variable one step further to account for different country groups so we have (FDI*H*EU) and (FDI*H*MENA) to capture the interaction between human capital and FDI in EU accession and MENA countries respectively. Table 6 summarizes these results. In the first and second columns we note that the 2SLS and the random effect estimates show a negative but statistically insignificant on FDI*H, which is contrary to the findings of Borensztein, et al (1998). We note, however, that (FDI*H*EU) has a positive and 
significant coefficient as shown in columns 3 and 4 of table 6 while the coefficient on (FDI*H*MENA) is statistically insignificant. These results suggest that FDI may have a positive effect on growth only if the human capital in the host country achieves a certain level. This positive effect only materializes in EU accession countries.

\section{CONCLUDING REMARKS}

MENA and CEE countries have been actively seeking FDI as a main component of their transition to the market economy as in CEE countries or in their search for new sources of growth as in MENA countries. We examine the link between FDI and growth in 6 MENA and 17 CEE countries using data averages over four periods: 19791984, 1985-1990, 1991-1996, and 1997-2002. We find that the volume of FDI inflow and its contribution to growth differed significantly across the two regions.

Our main findings suggest that the effect of FDI on economic growth is generally negative or statistically insignificant in MENA and non- EU accession CEE countries. Nevertheless, we find a positive and statistically significant effect of FDI on growth only in EU accession countries. We also find human capital stock to be an important vehicle through which FDI generates a positive effect on growth. This result holds only for EU accession countries and confirms the findings of Borensztein, et al (1998).

These results seem intuitive given the nature of the EU accession requirements. EU accession countries have generally faced stronger pressures and stricter performance criteria and deadlines than other countries in a way that shaped the above results. One may argue that the sheer size of FDI inflows to EU accession countries could explain the above results but we notice sizeable FDI inflows to non EU accession countries as in Russia for instance without generating any positive effect. It is intuitive therefore to conclude that FDI contribution to growth in transition economies is conditional upon implementing far-reaching economic reforms or signaling strong commitment to achieving such reforms.

These findings generate crucial implications for policy makers in developing countries that seek greater integration into the global economy. It suggests that for FDI to have a positive effect on growth, reform needs to be bold, serious and comprehensive with clear objectives and strong commitments on the part of the reforming country. EU accession countries seem to have provided the prototype for successful transition. By contrast, staggering reforms that are pre emptied with red tape obstacles in MENA and other countries do not generate the expected effect of FDI.

\section{REFERENCES}

1. Aghion, Philippe and Howitt, Peter (1992): A Model of Growth through Creative Destruction, Econometrica, March; 60(2): 323-51.

2. Agrawal, Pradeep (2000): Economic Impact of Foreign Direct Investment in South Asia. Working Paper, World Bank.

3. Akinlo, A. E. (2004): Foreign direct investment and growth in Nigeria An empirical investigation. Journal of Policy Modeling, 26, 627-639

4. Balasubramanyam, V., M. Salisu, and D. Sapsford (1996): Foreign Direct Investment and Growth in PE Countries. The Economic Journal, Vol. 106, No. 434, Jan. 92-105.

5. Barro, R. and J. W. Lee (2000): International Data on Educational Attainment: Updates and Implications, manuscript, Harvard University, (February).

6. Barro, R. and Sala-i-Martin, X. (1995): Economic Growth, McGraw-Hill, Cambridge, MA.

7. Brecher, R.A., and Diaz-Alejandro, C.F. (1977): Tariffs, Foreign Capital and Immeserizing Growth, Journal of International Economics, Vol.7, pp.317-22.

8. Bhagwati, J. N. (1978): The Theory of Immiserizing Growth: further applications, In International Trade and Money (ed. Michael B. Connolly and Alexander K. Swoboda), Toronto, University of Toronto Press.

9. Blomstrom, M., Lipsey, R., and M. Zejan. (1992): What Explains Developing Country Growth? NBER Working Paper, No. 4132

10. Borensztein, E., J. De Gregorio, and J.W. Lee (1998): How Does Foreign Direct Investment Affect Growth Journal of International Economics, Vol.45, No.1, 115-35.

11. Chen, C., Chang, L., and Y. Zhang. (1995): The Role of Foreign Direct Investment in China's Post-1978 Economic Development. World Development Vol.23, n4: 691-703

12. Grossman, G. and Helpman, E. (1991): Innovation and Growth in the Global Economy, MIT Press, Cambridge, MA. 
13. Kasibhatla, K. and B. Sawhney. (1996): Foreign Direct Investment and Economic Growth in the US: Evidence from Cointegration and Granger Causality Tests. Rivista Internazionale di Scienze Economiche e Commerciali, V43. n2: 411-20.

14. Makki, S. and A. Somwaru (2004): Impact of Foreign Direct Investment and Trade on Economic Growth: Evidence from Developing Countries, American Journal of Agricultural Economic, Vol. 86 Issue 3, August, 795-801.

15. Nair-Reichert, U. and D. Weinhold (2001): Causality tests for cross-country panels: a new look at FDI and economic growth in developing countries, Oxford Bulletin of Economics and Statistic, Vol. 63, Issue 2, 153-171.

16. Romer, P. (1990): Endogenous Technological Change. Journal of Political Economy, 98, 5, 71-102.

17. (1993): Idea gaps and object gaps in economic development, Journal of Monetary Economics, 32, No. 3,

18. UNCTAD, World Investment Report, Several Issues.

Table 1. Countries In The Sample

\begin{tabular}{|c|c|c|}
\hline MENA Countries & EU Acceded Countries & Other CEE Countries $^{\mathbf{1}}$ \\
\hline Algeria & Czech Republic & Albania \\
\hline Egypt & Estonia & Belarus \\
\hline Israel & Hungary & Croatia \\
\hline Morocco & Latvia & Moldova \\
\hline Tunis & Lithuania & Romania \\
\hline Turkey & Malta & Russia \\
\hline & Poland & Ukraine \\
\hline
\end{tabular}

Table 2. FDI Inflows, Millions Of US \$

\begin{tabular}{|l|c|c|c|c|c|c|c|}
\hline \multicolumn{1}{|c|}{ Country } & $\mathbf{1 9 8 0}$ & $\mathbf{1 9 9 0}$ & $\mathbf{1 9 9 5}$ & $\mathbf{2 0 0 0}$ & $\mathbf{2 0 0 1}$ & $\mathbf{2 0 0 2}$ & $\mathbf{1 9 9 0 - 2 0 0 2}$ Avg. \\
\hline Poland & 10.0 & 89.0 & 3659.0 & 9341.0 & 5713.0 & 4131.0 & 5108.2 \\
\hline Czech Republic & 0.0 & 72.0 & 2567.6 & 4984.4 & 5638.9 & 8482.7 & 3830.7 \\
\hline Hungary & 1.0 & 311.0 & 5103.5 & 2764.1 & 3936.0 & 2844.5 & 3285.1 \\
\hline Russia & 0.0 & 0.0 & 2065.0 & 2714.0 & 2469.0 & 3461.0 & 2691.4 \\
\hline Israel & 51.0 & 125.0 & 1581.0 & 5011.0 & 3549.0 & 1721.0 & 2287.0 \\
\hline Turkey & 18.0 & 684.0 & 885.0 & 982.0 & 3266.0 & 1038.0 & 1122.8 \\
\hline Slovakia & 0.0 & 93.0 & 258.4 & 1925.4 & 1584.1 & 4123.4 & 1079.9 \\
\hline Romania & 0.0 & 0.0 & 419.0 & 1037.0 & 1157.0 & 1144.0 & 923.0 \\
\hline Egypt & 548.3 & 734.0 & 595.2 & 1235.4 & 509.9 & 646.9 & 820.6 \\
\hline Croatia & 0.0 & 0.0 & 114.2 & 1088.7 & 1561.3 & 1124.0 & 814.6 \\
\hline Morocco & 89.4 & 165.0 & 332.0 & 215.4 & 2824.6 & 480.7 & 754.9 \\
\hline Bulgaria & 0.0 & 4.0 & 90.4 & 1001.5 & 812.9 & 904.7 & 531.5 \\
\hline Ukraine & 0.0 & 0.0 & 267.0 & 595.0 & 792.0 & 693.0 & 525.6 \\
\hline Algeria & 348.7 & 40.0 & 0.0 & 438.0 & 1196.0 & 1065.0 & 475.2 \\
\hline Tunisia & 246.5 & 90.5 & 322.6 & 778.8 & 486.4 & 821.3 & 464.5 \\
\hline Lithuania & 0.0 & 0.0 & 72.6 & 378.9 & 445.8 & 732.0 & 394.2 \\
\hline Slovenia & 0.0 & 4.3 & 151.9 & 137.4 & 369.0 & 1606.4 & 344.3 \\
\hline Latvia & 0.0 & 0.0 & 179.6 & 410.5 & 163.3 & 383.9 & 304.9 \\
\hline Estonia & 0.0 & 0.0 & 201.5 & 387.0 & 542.4 & 284.4 & 302.0 \\
\hline Malta & 26.6 & 45.8 & 131.6 & 621.8 & 280.8 & -428.2 & 233.1 \\
\hline Albania & 0.0 & 0.0 & 70.0 & 143.0 & 207.3 & 135.0 & 86.6 \\
\hline Moldova & 0.0 & 0.0 & 66.9 & 134.3 & 146.1 & 116.6 & 75.4 \\
\hline Source: & & & & &
\end{tabular}

Source: UNCTAD

\footnotetext{
${ }^{1}$ Although Bulgaria and Romania are now candidates for EU accession we considered them late reformers, as they are yet to join the EU by 2007.
} 
Table 3. Summary Statistics For EU Accession Countries

\begin{tabular}{|l|c|c|c|c|}
\hline \multicolumn{1}{|c|}{ Variable } & Mean & Std. Dev. & Min & Max \\
\hline Per Capita RGDP Growth & 4.0 & .7 & 3.2 & 5.5 \\
\hline Real Per Capita GDP US\$ & 4917.1 & 2659.9 & 2376.0 & 11387.7 \\
\hline Foreign Debt/GDP & 26.5 & 31.3 & .05 & 102.4 \\
\hline Labor force Millions & 3.7 & 5.9 & .1 & 19.8 \\
\hline FDI/GDP & $4.04 \mathrm{e}-02$ & $2.88 \mathrm{e}-02$ & $8.28 \mathrm{e}-03$ & $1.17 \mathrm{e}-01$ \\
\hline Exports/GDP & 59.6 & 18.6 & 24.6 & 91.0 \\
\hline I/GDP & 19.5 & 7.7 & 2.1 & 28.7 \\
\hline G/GDP & 18.9 & 3.2 & 10.2 & 22.7 \\
\hline Deflator & 105.6 & 60.7 & 33.0 & 250.2 \\
\hline Avg. Years of Education & 8.5 & 1.2 & 5.5 & 9.8 \\
\hline
\end{tabular}

Table 4. Summary Statistics For MENA Countries

\begin{tabular}{|l|c|c|c|c|}
\hline \multicolumn{1}{|c|}{ Variable } & Mean & Std. Dev. & Min & Max \\
\hline Per Capita RGDP Growth & 3.4 & 3.3 & -3.3 & 15.0 \\
\hline Real Per Capita GDP US\$ & 3657.9 & 4648.0 & 724.5 & 17013.0 \\
\hline Foreign Debt/GDP & 1286.7 & 6356.1 & .43 & 34322.7 \\
\hline Labor force Millions & 9.12 & 8.96 & .57 & 31.9 \\
\hline FDI/GDP & $9.27 \mathrm{e}-03$ & $9.69 \mathrm{e}-03$ & $1.47 \mathrm{e}-04$ & $3.81 \mathrm{e}-02$ \\
\hline Exports/GDP & 29.9 & 10.9 & 5.6 & 53.5 \\
\hline I/GDP & 15.2 & 11.3 & 1.25 & 39.5 \\
\hline G/GDP & 19.6 & 7.8 & 8.2 & 37.8 \\
\hline Deflator & 3987.8 & 19804.2 & .003 & 106868.7 \\
\hline Avg. Years of Education & 4.4 & 2.3 & 1.3 & 9.1 \\
\hline
\end{tabular}

Table 5. Estimates Of The Effect Of FDI On Growth - Dependent Variable Growth Rate Of Real Per Capita GDP

\begin{tabular}{|c|c|c|c|c|}
\hline \multirow[t]{2}{*}{ Regressors } & \multicolumn{2}{|c|}{1} & \multicolumn{2}{|c|}{2} \\
\hline & 2 SLS & $\mathrm{RE}$ & 2 SLS & $\mathrm{RE}$ \\
\hline \multirow[t]{2}{*}{ Initial GDP } & -.21 & -.48 & -.38 & .48 \\
\hline & $(.46)$ & $(.47)$ & $(.51)$ & $(.46)$ \\
\hline \multirow[t]{2}{*}{ Human Capital } & -.162 & -.92 & -.04 & -.60 \\
\hline & $(.60)$ & $(.76)$ & $(.61)$ & $(.60)$ \\
\hline \multirow[t]{2}{*}{$\begin{array}{l}\text { Domestic } \\
\text { Investment/GDP }\end{array}$} & $8.52 \mathrm{e}-10$ & $1.12 \mathrm{e}-9$ & $1.70 \mathrm{e}-09 * * *$ & $2.03 \mathrm{e}-09$ \\
\hline & $(7.69 \mathrm{e}-10)$ & $1.50 \mathrm{e}-09$ & $(5.54 \mathrm{e}-10)$ & $(1.49 \mathrm{e}-09)$ \\
\hline \multirow[t]{2}{*}{ Labor Force Growth } & -.22 & -.23 & $-.23 * *$ & -.11 \\
\hline & $(.13)$ & $(.14)$ & $(.12)$ & $(.13)$ \\
\hline \multirow[t]{2}{*}{ Exports/GDP } & -.03 & -.016 & -.06 & -.028 \\
\hline & $(.04)$ & $(.026)$ & $(.04)$ & $(.024)$ \\
\hline \multirow[t]{2}{*}{ Foreign Debt/GDP } & $-.0002 * * *$ & $-.0002 * * *$ & $-.0002 * * *$ & $-.0002 * * *$ \\
\hline & $(.00002)$ & $(.00007)$ & $(.00002)$ & $(.00006)$ \\
\hline \multirow[t]{2}{*}{$\begin{array}{l}\text { Government } \\
\text { Consumption/GDP }\end{array}$} & $.23 * * *$ & $-6.45 e-10$ & $.23 * * *$ & $-2.58 \mathrm{e}-10$ \\
\hline & $(.09)$ & $(1.56 \mathrm{e}-09)$ & $(.08)$ & $(1.30 \mathrm{e}-09)$ \\
\hline \multirow[t]{2}{*}{ Inflation } & $-6.65 \mathrm{e}-08 * * *$ & $-4.32 \mathrm{e}-08 * * *$ & $-6.11 \mathrm{e}-08 * * *$ & $-3.71 \mathrm{e}-08 * * *$ \\
\hline & $(6.94 \mathrm{e}-09)$ & $(8.48 \mathrm{e}-09)$ & $(6.99 \mathrm{e}-09)$ & $(7.58 \mathrm{e}-09)$ \\
\hline \multirow[t]{2}{*}{ FDI } & .42 & -.98 & $-5.49 * *$ & $-7.60 * * *$ \\
\hline & $(1.58)$ & $(1.15)$ & $(2.41)$ & $(2.20)$ \\
\hline \multirow[t]{2}{*}{ FDI*MENA } & & & 3.57 & 6.68 \\
\hline & & & $(3.17)$ & $(4.24)$ \\
\hline FDI*EU & & & $7.15 * *$ & $7.87 * * *$ \\
\hline
\end{tabular}




\begin{tabular}{|l|c|c|c|c|}
\hline & & & $(2.99)$ & $(2.43)$ \\
\hline F-Stats/Wald (Ch2) & $94.85^{* * *}$ & $39.27 * * *$ & $100.10^{* * *}$ & $53.5 * * *$ \\
\hline Adjusted R ${ }^{2}$ & 0.49 & .21 & 0.53 & 0.21 \\
\hline Obis. & 60 & 60 & 60 & 60 \\
\hline
\end{tabular}

- Constant suppressed for space.

Regression is based on 6-year averages for the periods 1979-1984, 1985-1990, 1991-1996, and 1997-2002.

Standard errors in parentheses with $* * *$ denoting significance at the $1 \%$ level and $* *$ denoting significance at the $5 \%$ level.

2SLS is the two stage least squares estimation. RE is the random effect instrumental variable regression.

Table 6. Estimates Of The Effect Of FDI On Growth - Dependent Variable Growth Rate Of Real Per Capita GDP

\begin{tabular}{|c|c|c|c|c|}
\hline \multirow[t]{2}{*}{ Regressors } & \multicolumn{2}{|c|}{1} & \multicolumn{2}{|c|}{2} \\
\hline & 2 SLS & $\mathrm{RE}$ & 2 SLS & $\mathrm{RE}$ \\
\hline \multirow[t]{2}{*}{ Initial GDP } & -.20 & -.23 & -.37 & -.32 \\
\hline & $(.48)$ & $(.53)$ & $(.51)$ & $(.53)$ \\
\hline \multirow[t]{2}{*}{ Human Capital } & -.13 & -.63 & .64 & -.34 \\
\hline & $(.77)$ & $(1.10)$ & $(.85)$ & $(1.06)$ \\
\hline \multirow[t]{2}{*}{$\begin{array}{l}\text { Domestic } \\
\text { Investment/GDP }\end{array}$} & $8.59 \mathrm{e}-10$ & $1.09 \mathrm{e}-09$ & $1.95 \mathrm{e}-09 * * *$ & $1.91 \mathrm{e}-09$ \\
\hline & $(7.64 \mathrm{e}-10)$ & $(1.69 \mathrm{e}-09)$ & $(7.41 \mathrm{e}-10)$ & $(1.72 \mathrm{e}-09)$ \\
\hline \multirow[t]{2}{*}{ Labor Force Growth } & -.22 & -.33 & $-.20 * *$ & -.23 \\
\hline & $(.13)$ & $(.20)$ & $(.10)$ & $(.17)$ \\
\hline \multirow[t]{2}{*}{ Exports/GDP } & -.03 & -.05 & -.07 & -.04 \\
\hline & $(.04)$ & $(.04)$ & $(.05)$ & $(.04)$ \\
\hline \multirow[t]{2}{*}{ Foreign Debt/GDP } & $-.0002 * * *$ & $-.0002 * * *$ & $-.0002 * * *$ & $-.0002 * * *$ \\
\hline & $(.00002)$ & $(.00007)$ & $(.00002)$ & $(.00006)$ \\
\hline \multirow[t]{2}{*}{$\begin{array}{l}\text { Government } \\
\text { Consumption/GDP }\end{array}$} & $.23^{* *}$ & $.19 * *$ & $.22 * *$ & .14 \\
\hline & $(.09)$ & $(.09)$ & $(.09)$ & $(.09)$ \\
\hline \multirow[t]{2}{*}{ Inflation } & $-6.64 \mathrm{e}-08 * * *$ & $-4.48 \mathrm{e}-08 * * *$ & $-5.97 \mathrm{e}-08 * * *$ & $-3.86 \mathrm{e}-08 * * *$ \\
\hline & $(6.95 \mathrm{e}-09)$ & $(1.11 \mathrm{e}-08)$ & $(6.99 \mathrm{e}-09)$ & $(1.07 \mathrm{e}-08)$ \\
\hline \multirow[t]{2}{*}{ FDI } & .88 & 2.55 & 4.88 & 3.46 \\
\hline & $(4.37)$ & $(8.49)$ & $(4.55)$ & $(8.07)$ \\
\hline \multirow[t]{2}{*}{ FDI*H } & -.54 & -.77 & -1.30 & -1.22 \\
\hline & $(.55)$ & $(1.02)$ & $(.71)$ & $(1.02)$ \\
\hline \multirow[t]{2}{*}{ FDI*H*EU } & & & $8.99 * *$ & $7.44 * *$ \\
\hline & & & $(3.97)$ & $(3.57)$ \\
\hline \multirow[t]{2}{*}{ FDI*H*MENA } & & & -2.04 & -4.72 \\
\hline & & & $(6.01)$ & $(8.25)$ \\
\hline F-Stats/Wald (Ch2) & 86.62 & $40.11 * * *$ & 99.00 & $46.70 * * *$ \\
\hline Adjusted $\mathrm{R}^{2}$ & 0.48 & 0.43 & 0.53 & 0.50 \\
\hline Obis. & 60 & 60 & 60 & 60 \\
\hline
\end{tabular}

Constant suppressed for space.

Regression is based on 6-year averages for the periods 1979-1984, 1985-1990, 1991-1996, and 1997-2002.

Standard errors in parentheses with *** denoting significance at the $1 \%$ level and $* *$ denoting significance at the $5 \%$ level.

2SLS is the two stage least squares estimation. RE is the random effect instrumental variable regression. 